\title{
ANALISIS FAKTOR PERILAKU PEJALAN KAKI TERHADAP KESELAMATAN DI JALAN RAYA PADA WILAYAH JABODETABEK
}

\author{
Farah Rizkia Ananda ${ }^{1}$ dan Leksmono Suryo Putranto ${ }^{2}$ \\ ${ }^{1}$ Program Studi Sarjana Teknik Sipil, Universitas Tarumanagara, Jl. Letjen S. Parman No.1 Jakarta \\ farah.325160152@stu.untar.ac.id \\ ${ }^{2}$ Program Studi Sarjana Teknik Sipil, Universitas Tarumanagara, Jl. Letjen S. Parman No.1 Jakarta \\ leksmonop@stu.untar.ac.id
}

Masuk: 15-07-2021, revisi: 25-08-2021, diterima untuk diterbitkan: 30-08-2021

\begin{abstract}
Pedestrian behavior that is not predictable and cannot be controlled effectively results in pedestrians not complying with traffic rules and may be ending up in accidents. This study aims to determine the factors formed and determine the influence of demographics on pedestrian behavior in Indonesia. The questions on the Indonesian $P B Q$ (Pedestrian Behavior Questionnaire) are adapted from an international questionnaire that has been tested in several countries and confirmed by factor analysis. The results of the analysis showed that from the 23 variables of pedestrian behavior, 5 (five) variables are reduced until the remaining 18 variables. The 18 pedestrian behavior variables form 6 factors, namely violations, errors, lapses, aggressive behavior, positive behavior, and traffic light violations. Violations and lapses in Indonesia are mostly committed by young adults, non-private employees, and those who have expenses of less than four million five hundred rupiah per month. Those who in the adult group show positve behavior more oftenly. Those who walk more than once a week show errors and positive behavior more oftenly. Those who have been involved in accidents show violations and aggressive behavior more oftenly.
\end{abstract}

Keywords: pedestrian behavior; violations; lapses; errors; positive behavior

\begin{abstract}
ABSTRAK
Perilaku pejalan kaki yang tidak mudah diprediksi dan tidak dapat dikendalikan secara efektif mengakibatkan pejalan kaki tidak mematuhi aturan lalu lintas sehingga terjadi kecelakaan. Penelitian ini bertujuan untuk mengetahui faktor-faktor yang terbentuk serta mengetahui pengaruh demografis terhadap perilaku pejalan kaki di Indonesia. Pertanyaan-pertanyaan pada Indonesia PBQ (Pedestrian Behavior Questionnaire) diadaptasi dari kuesioner Internasional yang telah diuji di beberapa negara dan dikonfirmasi dengan analisis faktor. Hasil analisis menunjukkan dari ke-23 variabel perilaku pejalan kaki tereduksi sebanyak 5 (lima) variabel hingga tersisa 18 variabel. Ke-18 variabel perilaku pejalan kaki tersebut membentuk 6 faktor yaitu violations, errors, lapses, perilaku agresif, perilaku positif, dan pelanggaran lampu lalu lintas. Pelanggaran violations dan lapses di Indonesia paling banyak dilakukan oleh kelompok dewasa muda, pekerjaan bukan pegawai swasta, dan yang memiliki pengeluaran kurang dari empat juta lima ratus rupiah per bulan. Mereka yang termasuk kelompok dewasa madya lebih sering menunjukkan perilaku positif. Mereka yang berjalan kaki lebih dari sekali dalam seminggu lebih sering menunjukkan kesalahan errors dan perilaku positif. Mereka yang pernah terlibat kecelakaan lebih sering menunjukkan perilaku violations dan agresif.
\end{abstract}

Kata kunci: perilaku pejalan kaki; violations; lapses; errors; perilaku positif

\section{PENDAHULUAN}

Pada tahun 2010, jumlah kematian di seluruh dunia akibat kecelakaan lalu lintas mencapai 1,23 juta orang. Menurut WHO (2013) secara global tercatat sekitar kurang lebih 22\% dari total jumlah kematian merupakan kematian pejalan kaki. Gambar 1 menggambarkan secara global kematian diakibatkan kecelakaan lalu lintas yang terjadi pada $31 \%$ pengguna mobil, $23 \%$ pengguna kendaraan bermotor roda 2-3, 5\% pengguna sepeda, dan $19 \%$ lainnya tidak disebutkan. 


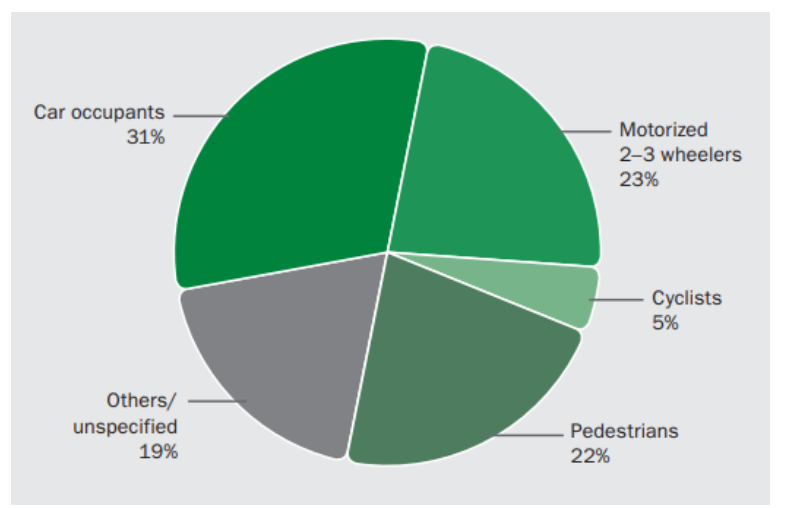

Gambar 1. Distribusi kematian lalu lintas berdasarkan jenis pengguna secara global, 2010 (Sumber: WHO, 2013)

Pejalan kaki memiliki potensi kecelakaan lalu lintas yang lebih tinggi daripada kendaraan bermotor (Zhang et al, 2014). Sebagian besar kecelakaan pejalan kaki terjadi ketika mereka tidak mematuhi aturan lalu lintas. Mayoritas kecelakaan pejalan kaki terjadi saat sedang menyeberang jalan. Junaedi (2014) melakukan survei terhadap 250 pejalan kaki yang menyeberang jalan di Kota Bandar Lampung. Dalam penelitiannya, ia menemukan bahwa kecepatan rata-rata pejalan kaki saat menyeberang jalan adalah 1,28 meter per detik. Ia juga menemukan bahwa 6,4\% pejalan kaki melakukan incomplete crossing. Incomplete crossing terjadi saat pejalan kaki tidak dapat melanjutkan penyeberangannya karena lampu lalu lintas yang telah berubah menjadi hijau sebelum selesai menyeberang. Hal ini dapat menyebabkan kecelakaan lalu lintas karena adanya konflik antara pejalan kaki dengan kendaraan bermotor.

Beberapa pejalan kaki memilih tidak menyeberang di zebra cross karena terburu-buru sehingga pejalan kaki telah melanggar peraturan lalu lintas. Waktu tunggu sinyal juga mempengaruhi perilaku pejalan kaki. Waktu tunggu sinyal yang terlalu lama membuat pejalan kaki menjadi tidak sabar dan akhirnya mereka melanggar lalu lintas (Tiwari et al, 2007). Pelanggaran ini sangat berisiko karena dapat menyebabkan kecelakaan lalu lintas atau dapat berujung kematian. Oleh karena itu, penting untuk memahami perilaku pejalan kaki saat menyeberang guna keselamatan jalan. Berbagai metode yang telah dilakukan oleh peneliti pendahulu untuk mengamati dan memahami perilaku pejalan kaki dalam situasi yang berbeda. Salah satu metode untuk memahami perilaku pejalan kaki yaitu menggunakan laporan diri berupa PBQ (Pedestrian Behavior Questionnaire). Pada penelitian ini, selain mengembangkan PBQ versi Indonesia, juga bertujuan untuk mengetahui faktor-faktor yang membentuk perilaku pejalan kaki di Indonesia terutama pada wilayah Jabodetabek dan mengetahui pengaruh demografis terhadap perilaku pejalan kaki di Indonesia.

\section{Pedestrian Behavior Questionnaire (PBQ)}

Pada tahun 2004, Elliot dan Baughan mengembangkan kuesioner di Inggris untuk memahami perilaku pejalan kaki dan perilaku pengendara sepeda khususnya para remaja, yaitu ARBQ (Adolescent Road User Behavior Questionnaire). ARBQ membedakan perilaku pengguna jalan menjadi tiga komponen, yaitu: (a) penyeberangan jalan yang tidak aman; (b) berbahayanya bermain di jalan; dan (c) perilaku perlindungan. ARBQ diusulkan menjadi kedua versi, yaitu versi panjang sebanyak 43 item dan versi pendek sebanyak 21 item, dan sebagian besar didukung oleh studi pelengkap dari Selandia Baru. ARBQ versi pendek dibuktikan valid di Spanyol dan Belgium (Deb et al, 2017).

Granié et al. (2013) mengembangkan salah satu kuesioner yang paling lengkap, yaitu Pedestrian Behavior Scale (PBS). Para peneliti mengelola dan memvalidasi PBS di Perancis untuk segala usia. PBS terdapat dua versi yaitu versi panjang sebanyak 37 item dan versi pendek sebanyak 23 item. PBS mencakup lima kategori jenis perilaku pejalan kaki, yaitu perilaku positif, perilaku agresif, errors, violations, lapses. Perilaku positif dimana perilaku yang menghindari pelanggaran dan berupaya untuk mematuhi peraturan lalu lintas, seperti pejalan kaki yang menyeberang di zebra cross dan menunggu lampu lalu lintas khusus pejalan kaki berubah menjadi hijau. Perilaku agresif dimana perilaku yang berniat untuk mengganggu dan membahayakan pengguna jalan lainnya, seperti pejalan kaki yang marah terhadap pengguna jalan lain karena tidak memberikan kesempatan untuk menyeberang atau pejalan kaki yang sengaja bergerak secara perlahan saat menyeberang. Errors, kurangnya pengetahuan terhadap aturan lalu lintas, seperti pejalan kaki yang berjalan di jalur sepeda. Violations, pelanggaran yang dilakukan secara sengaja dari aturan sosial tanpa menyebabkan cidera, seperti pejalan kaki yang tidak menggunakan zebra cross saat menyeberang. Lapses, pelanggaran yang dilakukan secara tidak sengaja karena kurangnya konsentrasi, seperti pejalan kaki yang lupa melihat kanan kiri sebelum menyeberang karena memikirkan hal lain. 
Pada tahun 2016, Papadimitriou et al, mengaplikasikan PBQ (Pedestrian Behavior Questionnaire) di Yunani untuk mengembangkan model pilihan penyeberangan pejalan kaki berdasarkan jalan, lalu lintas, dan faktor manusia. Para peneliti di Yunani mengelompokkan skala perilaku pejalan kaki menjadi tiga komponen, yaitu: (a) pengambilan risiko dan pengoptimalan (misalnya, kecenderungan menyeberang di luar zebra cross untuk menghemat waktu); (b) konservatif (misalnya, menyeberang di zebra cross dengan memperhatikan APILL); dan (c) kenyamanan atau kesenangan pejalan kaki (misalnya, kecenderungan sering berjalan untuk kesehatan). Hasil pemodelan yang dilakukan oleh para peneliti menunjukkan bahwa pilihan pejalan kaki dalam menyeberang dipengaruhi oleh jenis jalan, arus lalu lintas, dan kontrol lalu lintas.

PBQ juga dapat membantu pejalan kaki menyadari kecenderungan mereka saat melintasi jalan dan menyadari aturan lalu lintas sehingga pejalan kaki dapat mengubah perilaku berisiko mereka dalam berjalan kaki. Metode kuesioner ini cenderung bermanfaat untuk penelitian yang meneliti keselamatan pejalan kaki, karena akan memberikan kerangka kerja untuk mempelajari sejumlah masalah penting, seperti jenis perilaku mana yang terlibat dalam kecelakaan di jalan raya dan mekanisme psikologis apa yang menjelaskan perilaku ini.

\section{Perilaku berisiko pejalan kaki}

Dalam kondisi lalu lintas sehari-hari, pejalan kaki menunjukkan berbagai macam perilaku. Menurut Deb et al. (2017), faktor-faktor utama yang ditemukan secara signifikan dalam penelitian perilaku pejalan kaki, diantaranya: faktor struktural (seperti desain jalan, rambu lalu lintas dan desain sinyal, kepadatan lalu lintas); faktor lingkungan (seperti batas kecepatan, jenis kendaraan, kepadatan populasi, kondisi cuaca); dan faktor manusia, baik pengemudi maupun pejalan kaki (seperti kesalahan dalam mengambil keputusan, tingkat alkohol, usia, kurangnya pengetahuan, dan kepribadian).

Granie et al. (2013) menemukan bahwa laki-laki lebih mengekspresikan perilaku agresif dan violations dibandingkan perempuan. Perempuan lebih berhati-hati dan lebih menaati peraturan lalu lintas. Antic et al. (2016) menemukan bahwa pejalan kaki yang lebih muda ( $\leq 25$ tahun) lebih banyak menunjukkan violations dari pejalan kaki yang lebih tua (> 25 tahun). Pejalan kaki yang lebih tua lebih banyak menunjukkan lapses. Karena kemampuan fisik yang berkurang sehingga mempengaruhi kemampuan dalam berkonsentrasi. Antic et al. (2016) juga menemukan errors pada pejalan kaki yang berjalan karena kebutuhan seperti pergi ke pasar atau sekolah dan lapses pada pejalan kaki yang memilih berjalan untuk kesenangan seperti berolahraga. Ia juga menemukan errors pada kelompok yang menempuh jarak harian dalam berjalan dengan jarak terjauh dalam sehari (800-1300 meter atau lebih), karena konsentrasi pejalan kaki akan menurun.

\section{METODE PENELITIAN}

Dalam penelitian ini, platform yang digunakan untuk mengumpulkan data responden adalah Google Form dan disebarluaskan secara online. Pengguna jalan yang akan diteliti adalah pejalan kaki yang tinggal atau beraktivitas sehari-hari di wilayah JABODETABEK (Jakarta, Bogor, Depok, Tangerang, dan Bekasi). Untuk menguji validitas dan reliabilitas kuesioner, dilakukan uji coba kepada 20 responden. Setelah memperbaiki kalimat pertanyaan yang tidak valid dan tidak reliabel, final kuesioner kemudian dibagikan kepada 150 responden. Skala yang digunakan dalam kuesioner adalah skala likert. Responden diminta untuk menilai apakah mereka hampir tidak pernah (1), jarang (2), sering (3), atau hampir selalu (4) di setiap pertanyaan kuesioner. Kuesioner dalam penelitian ini terdapat dua bagian. Bagian pertama berisi pertanyaan tentang demografis dan karakteristik sosial, seperti jenis kelamin, usia, tempat tinggal, tempat bekerja atau beraktivitas sehari-hari, pekerjaan, pengeluaran per bulan, frekuensi berjalan kaki, jarak kemampuan berjalan, dan keterlibatan dalam kecelakaan. Bagian kedua berisi 23 pertanyaan perilaku pejalan kaki yang diadaptasi dari versi pendek PBQ oleh Granie et al. (2013), yang dibagi menjadi lima faktor yaitu perilaku positif (4 items), errors (5 items), violations (6 items), lapses (4 items), dan perilaku agresif (4 items).

Dari 150 responden, sebagian besar $(58 \%)$ berasal dari kelompok usia dewasa muda. Usia responden berkisar antara 16 dan 73 tahun dengan rata-rata 36 tahun dan standar deviasi 15 tahun. Sebagian besar responden (57\%) tinggal di Jabodetabek dan sebagian besar (66\%) bekerja di Jakarta. Sebagian besar responden (39\%) adalah karyawan swasta dan $29 \%$ adalah mahasiswa. Sebagian besar responden (61\%) berpenghasilan kurang dari upah minimum regional 4,5 juta rupiah. Sebagian besar responden (37\%) berjalan kaki setiap hari. Sebagian besar responden (43\%) mampu berjalan antara 100 sampai 500m. Hanya kurang dari 6\% dari responden telah terlibat dalam setidaknya kecelakaan.

Alur atau tahapan dari penelitian ini digambarkan dalam diagram seperti pada gambar 2 sebagai berikut. 


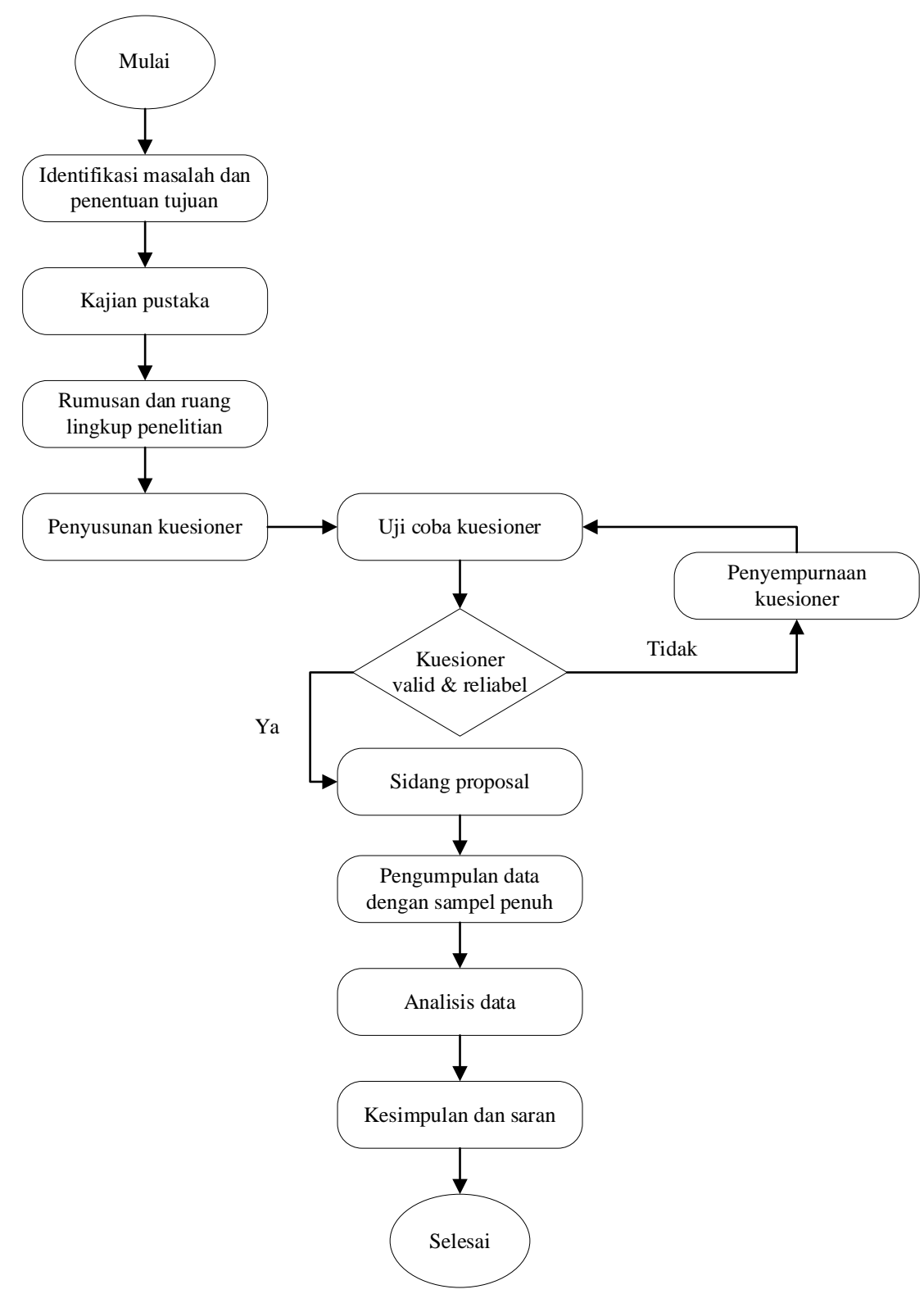

Gambar 2. Diagram alur penelitian

PBQ sementara yang diuji pada 20 responden digunakan untuk melakukan uji validitas dan reliabilitas. Uji validitas dilakukan untuk mengetahui apakah butir pertanyaan dalam kuesioner sudah valid atau belum untuk mengukur variabel yang akan diteliti. Uji validitas dilakukan dengan menggunakan teknik korelasi Spearman dengan tingkat signifikan <0,05 dinyatakan valid. Sedangkan uji reliabilitas dilakukan untuk mengetahui konsistensi hasil pengukuran apabila dilakukan pengukuran dua kali atau lebih terhadap gejala yang sama dengan menggunakan alat pengukur yang sama pula. Uji reliabilitas dilakukan dengan metode Cronbach's Alpha dengan tingkat signifikan $>0,60$ dinyatakan reliabel. Dalam hasil analisis uji coba PBQ terdapat dua item pada perilaku positif dan satu item pada errors dinyatakan tidak valid sehingga kalimat pertanyaan diperbaiki. Dengan sampel penuh, 150 responden, semua item dinyatakan valid. Namun, hasil uji reliabilitas pada perilaku positif dan errors dinyatakan tidak reliabel $(<0,60)$ sehingga perlu untuk mempertimbangkan kembali dalam menggunakan item pada pertanyaan ini dengan bijak. Setelah dilakukan uji validitas dan reliabilitas, lalu dilanjutkan dengan analisis faktor. IBM SPSS Statistics 23 digunakan untuk membantu menganalisis hasil penelitian.

Pada hasil analisis faktor yang dilakukan Putranto dan Ananda (2021) ada beberapa item yang dihilangkan karena nilai MSA (Measure of Sampling Adequacy) < 0,5. Setelah dilakukan 4 (empat) kali trial, hasil akhir menunjukkan nilai Kaiser-Meyer-Olkin Measure of Sampling Adequacy sebesar 0,749 (> 0,6) dan nilai signifikansi Bartlett's Test of Sphericity kurang dari 0,001. Dari ke-23 item perilaku pejalan kaki terdapat 5 (lima) item yang direduksi. Hasil akhir menunjukkan 18 item yang memengaruhi perilaku pejalan kaki Indonesia. Dari hasil ini membentuk 6 (enam) 
faktor perilaku pejalan kaki di Indonesia yaitu lapses, violations, errors, perilaku agresif, pelanggaran lampu lalu lintas, dan perilaku positif. Total keenam faktor yang terbentuk mampu menjelaskan variabel sebesar 64,948\%. Item dan nilai loading factor perilaku pejalan kaki dapat dilihat pada tabel 1. Setelah dilakukan analisis faktor, dilanjutkan dengan uji selisih rataan guna mengetahui pengaruh demografis terhadap perilaku pejalan kaki di Indonesia.

Tabel 1. Item dan loading factor perilaku pejalan kaki di Indonesia

\begin{tabular}{|c|c|c|c|c|c|c|c|}
\hline & \multirow[b]{2}{*}{ Item } & \multicolumn{6}{|c|}{ Loading Factor } \\
\hline & & Lapses & Agresif & Violations & Errors & $\begin{array}{l}\text { Lampu } \\
\text { LL }\end{array}$ & Positif \\
\hline D2 & $\begin{array}{l}\text { Saya lupa melihat kanan kiri sebelum me- } \\
\text { nyeberang karena saya sedang berbincang } \\
\text { dengan teman }\end{array}$ & 0,823 & & & & & \\
\hline D4 & $\begin{array}{l}\text { Saya lupa melihat kanan kiri sebelum me- } \\
\text { nyeberang karena terburu-buru }\end{array}$ & 0,760 & & & & & \\
\hline D3 & $\begin{array}{l}\text { Saya lupa melihat kanan kiri sebelum me- } \\
\text { nyeberang karena ingin bergabung dengan } \\
\text { pejalan kaki lainnya }\end{array}$ & 0,740 & & & & & \\
\hline D1 & $\begin{array}{l}\text { Saya lupa melihat kanan kiri sebelum me- } \\
\text { nyeberang karena saya sedang memikirkan } \\
\text { sesuatu }\end{array}$ & 0,701 & & & & & \\
\hline E2 & $\begin{array}{l}\text { Saya marah kepada pengemudi dan memukul } \\
\text { kendaraannya }\end{array}$ & & 0,868 & & & & \\
\hline E1 & $\begin{array}{l}\text { Saya marah kepada pengguna jalan lainnya } \\
\text { (pejalan kaki, pesepeda, pengemudi, dll) dan } \\
\text { menghina mereka }\end{array}$ & & 0,841 & & & & \\
\hline E4 & $\begin{array}{l}\text { Saya berteriak kepada pengemudi karena } \\
\text { tidak memberi saya jalan untuk menyeberang }\end{array}$ & & 0,690 & & & & \\
\hline E3 & $\begin{array}{l}\text { Saya sengaja bergerak perlahan saat menye- } \\
\text { berang jalan untuk mengganggu pengemudi }\end{array}$ & & 0,662 & & & & \\
\hline $\mathrm{C} 1$ & $\begin{array}{l}\text { Saya menyeberang di luar zebra cross walau- } \\
\text { pun lokasinya dekat }\end{array}$ & & & 0,716 & & & \\
\hline C6 & $\begin{array}{l}\text { Saya mendengarkan musik menggunakan } \\
\text { earphone saat menyeberang }\end{array}$ & & & 0,626 & & & \\
\hline $\mathrm{C} 2$ & $\begin{array}{l}\text { Saya menghindari penggunaan jembatan pe- } \\
\text { nyeberangan (JPO) }\end{array}$ & & & 0,618 & & & \\
\hline C5 & $\begin{array}{l}\text { Saya bermain gadget saat menyeberang } \\
\text { (menelpon atau menggunakan maps/sosial } \\
\text { media) }\end{array}$ & & & 0,570 & & & \\
\hline B5 & $\begin{array}{l}\text { Di jalan dua arah, saya menyeberangi bagian } \\
\text { pertama dan menunggu di tengah jalan untuk } \\
\text { menyeberangi bagian kedua }\end{array}$ & & & & 0,733 & & \\
\hline B4 & $\begin{array}{l}\text { Ketika saya ingin mendahului orang yang } \\
\text { bergerak lambat dan saya tidak memiliki cu- } \\
\text { kup ruang untuk melakukannya di trotoar, } \\
\text { saya pergi ke jalan }\end{array}$ & & & & 0,648 & & \\
\hline B3 & $\begin{array}{l}\text { Saya tetap menyeberang walaupun kenda- } \\
\text { raan masih melaju karena saya menganggap } \\
\text { masih ada cukup jarak bagi kendaraan untuk } \\
\text { berhenti }\end{array}$ & & & & 0,582 & & \\
\hline $\mathrm{C} 3$ & $\begin{array}{l}\text { Saya tetap menyeberang walaupun lampu } \\
\text { merah untuk pejalan kaki menyala }\end{array}$ & & & & & 0,874 & \\
\hline $\mathrm{C} 4$ & $\begin{array}{l}\text { Saya menyeberang walaupun lampu hijau } \\
\text { masih menyala untuk kendaraan }\end{array}$ & & & & & 0,620 & \\
\hline A4 & $\begin{array}{l}\text { Saya fokus melihat lampu lalu lintas dan } \\
\text { segera menyeberang setelah lampu lalu lintas } \\
\text { untuk pejalan kaki berubah menjadi hijau }\end{array}$ & & & & & & 0,864 \\
\hline
\end{tabular}

(Sumber: Putranto dan Ananda, 2021) 


\section{HASIL DAN PEMBAHASAN}

Untuk mengetahui apakah adanya pengaruh demografis terhadap perilaku pejalan kaki Indonesia atau tidak, dilakukan uji selisih rataan. Adanya perbedaan rataan yang nyata atau tidak dilihat dari nilai signifikansi pada tabel independent sample t-test. Independent sample t-test merupakan t-test yang dilakukan dengan membandingkan rataan dua kelompok data. Nilai signifikan kurang dari 0,05 maka dikatakan adanya perbedaan rataan antara kedua variabel yang diteliti. Hasil uji selisih rataan akan dirangkum pada tabel 2 sampai dengan tabel 8.

Tabel 2. Uji selisih rataan berdasarkan jenis kelamin

\begin{tabular}{lccccccc}
\hline \multirow{2}{*}{ Jenis Kelamin } & \multirow{2}{*}{$\mathrm{N}$} & \multicolumn{5}{c}{ Nilai Selisih Rataan } \\
\cline { 3 - 7 } & 77 & 1,4643 & 1,3571 & 1,6052 & 2,3182 & 1,3571 & 1,2078 \\
\hline Laki-laki & 73 & 1,3938 & 1,2089 & 1,5137 & 2,1151 & 1,2192 & 1,2055 \\
Perempuan & & 0,0705 & 0,1482 & 0,0915 & 0,2031 & 0,1380 & 0,0023 \\
Selisih Rataan & & 0,453 & 0,092 & 0,296 & 0,093 & 0,121 & 0,979 \\
Tingkat Signifikan & & Tidak & Tidak & Tidak & Tidak & Tidak & Tidak \\
Signifikan? (Ya/Tidak) & & & & & & Pidak
\end{tabular}

Pada tabel 2 diatas menunjukkan bahwa tidak ada perbedaan secara signifikan antara laki-laki dan perempuan terhadap keenam faktor perilaku pejalan kaki tersebut. Hal ini dapat dilihat dari nilai tingkat signifikan yang >0,05.

Tabel 3. Uji selisih rataan berdasarkan usia

\begin{tabular}{lccccccc}
\hline \multirow{2}{*}{ Usia } & \multirow{2}{*}{$\mathrm{N}$} & \multicolumn{5}{c}{ Nilai Selisih Rataan } \\
\cline { 3 - 7 } & & Lapse & Agresif & Violation & Error & Lampu LL & Positif \\
\hline 40 & 1,2143 & 1,2262 & 1,3317 & 2,1444 & 1,2222 & 1,1111 \\
<40 & 87 & 1,5862 & 1,3276 & 1,7264 & 2,2736 & 1,3391 & 1,2759 \\
Selisih Rataan & & $-0,3719$ & $-0,1014$ & $-0,3947$ & $-0,1291$ & $-0,1169$ & $-0,1648$ \\
Tingkat Signifikan & $<0,001$ & 0,259 & $<0,001$ & 0,292 & 0,198 & 0,036 \\
Signifikan? (Ya/Tidak) & & Ya & Tidak & Ya & Tidak & Tidak & Ya \\
\hline
\end{tabular}

Pada tabel 3 diatas menunjukkan lapses dan violations memengaruhi perilaku pejalan kaki. Hal ini terlihat pada nilai tingkat signifikan sebesar $<0,001(<0,05)$. Pada kolom lapses kelompok usia dewasa muda memiliki nilai 1,5862 dan kelompok dewasa madya sebesar 1,2143. Kemudian kolom violations kelompok usia dewasa muda memiliki nilai 1,7624 dan kelompok dewasa madya sebesar 1,3317. Hal ini menandakan bahwa kelompok usia dewasa muda cenderung lebih sering melakukan lapses dan violations dibandingkan dengan kelompok usia dewasa madya. Mereka yang termasuk kelompok usia dewasa madya lebih sering menunjukkan perilaku positif. Hasil ini menyatakan bahwa kelompok usia muda kurang mematuhi peraturan lalu lintas dan kelompok dewasa madya lebih berhati-hati dalam berjalan maupun menyeberang.

Tabel 4. Uji selisih rataan berdasarkan tempat tinggal

\begin{tabular}{lccccccc}
\hline \multirow{2}{*}{ Tempat Tinggal } & \multirow{2}{*}{$\mathrm{N}$} & \multicolumn{5}{c}{ Nilai Selisih Rataan } \\
\cline { 3 - 7 } & & Lapse & Agresif & Violation & Error & Lampu LL & Positif \\
\hline Jakarta & 65 & 1,3538 & 1,3423 & 1,5062 & 2,1385 & 1,3231 & 1,2154 \\
Non-Jakarta & 85 & 1,4882 & 1,2412 & 1,6024 & 2,2812 & 1,2647 & 1,2000 \\
Selisih Rataan & & $-0,1344$ & 0,1011 & $-0,0962$ & $-0,1427$ & 0,0584 & 0,0154 \\
Tingkat Signifikan & & 0,155 & 0,258 & 0,276 & 0,242 & 0,519 & 0,859 \\
Signifikan? (Ya/Tidak) & & Tidak & Tidak & Tidak & Tidak & Tidak & Tidak \\
\hline
\end{tabular}

Tabel 5. Uji selisih rataan berdasarkan tempat bekerja

\begin{tabular}{lccccccc}
\hline \multirow{2}{*}{ Tempat Bekerja } & \multirow{2}{*}{$\mathrm{N}$} & \multicolumn{5}{c}{ Nilai Selisih Rataan } \\
\cline { 3 - 7 } & & Lapse & Agresif & Violation & Error & Lampu LL & Positif \\
\hline Jakarta & 99 & 1,3990 & 1,3283 & 1,5374 & 2,1687 & 1,3232 & 1,2121 \\
Non-Jakarta & 51 & 1,4902 & 1,2010 & 1,6059 & 2,3176 & 1,2255 & 1,1961 \\
Selisih Rataan & & $-0,0912$ & $-0,1273$ & $-0,0685$ & $-0,1490$ & 0,0977 & 0,0160 \\
Tingkat Signifikan & & 0,357 & 0,113 & 0,458 & 0,244 & 0,302 & 0,859 \\
Signifikan? (Ya/Tidak) & & Tidak & Tidak & Tidak & Tidak & Tidak & Tidak \\
\hline
\end{tabular}


Pada tabel 4 dan tabel 5 diatas menunjukkan bahwa tidak ada perbedaan secara signifikan antara tempat tinggal atau tempat bekerja di wilayah Jakarta dan Non-Jakarta terhadap keenam faktor perilaku pejalan kaki tersebut.

Secara mengejutkan ternyata jenis pekerjaan berpengaruh pada perilaku pejalan kaki. Pada tabel 6 dibawah menunjukkan terdapat satu perilaku pejalan kaki yang memiliki nilai signifikansi $0,024(>0,05)$. Hal ini menjelaskan bahwa responden yang memiliki pekerjaan bukan pegawai swasta lebih cenderung melakukan pelanggaran violations dibandingkan dengan responden yang bekerja sebagai pegawai swasta. Namun, belum ada pembahasan mengenai pengaruh jenis pekerjaan terhadap perilaku pejalan kaki.

Tabel 6. Uji selisih rataan berdasarkan jenis pekerjaan

\begin{tabular}{|c|c|c|c|c|c|c|c|}
\hline \multirow{2}{*}{ Jenis Pekerjaan } & \multirow{2}{*}{$\mathrm{N}$} & \multicolumn{6}{|c|}{ Nilai Selisih Rataan } \\
\hline & & Lapse & Agresif & Violation & Error & Lampu LL & Positif \\
\hline Pegawai Swasta & 59 & 1,3475 & 1,2288 & 1,4441 & 2,2441 & 1,2797 & 1,1525 \\
\hline Lainnya & 91 & 1,4835 & 1,3214 & 1,6363 & 2,2033 & 1,2967 & 1,2418 \\
\hline Selisih Rataan & & $-0,1361$ & $-0,0926$ & $-0,1922$ & 0,0408 & $-0,0170$ & $-0,0892$ \\
\hline Tingkat Signifikan & & 0,155 & 0,307 & 0,024 & 0,743 & 0,853 & 0,272 \\
\hline Signifikan? (Ya/Tidak) & & Tidak & Tidak & $\mathrm{Ya}$ & Tidak & Tidak & Tidak \\
\hline
\end{tabular}

Hasil di luar dugaan juga terjadi pada kelompok responden dengan pengeluaran per bulan yang lebih rendah $(<\mathrm{Rp} 4.500 .000)$ cenderung lebih sering menunjukkan perilaku lapses dan violations dibandingkan kelompok responden dengan pengeluaran per bulan yang lebih tinggi ( $\geq$ Rp4.500.000). Namun, belum ada pembahasan mengenai pengaruh pengeluaran per bulan terhadap perilaku pejalan kaki. Nilai signifikan pada lapses dan violations yang masing-masing bernilai $<0,001 \quad(<0,05)$ menunjukkan bahwa pengeluaran per buan memengaruhi perilaku pejalan kaki. Hal ini dapat dilihat pada tabel 7.

Tabel 7. Uji selisih rataan berdasarkan pengeluaran per bulan

\begin{tabular}{lccccccc}
\hline \multirow{2}{*}{ Pengeluaran Per Bulan } & \multirow{2}{*}{$\mathrm{N}$} & \multicolumn{5}{c}{ Nilai Selisih Rataan } \\
\cline { 3 - 7 } & & Lapse & Agresif & Violation & Error & Lampu LL & Positif \\
\hline R R4.500.000 & 58 & 1,2500 & 1,2931 & 1,3638 & 2,1138 & 1,2759 & 1,1034 \\
< Rp4.500.000 & 92 & 1,5435 & 1,2799 & 1,6848 & 2,2859 & 1,2989 & 1,2717 \\
Selisih Rataan & & $-0,2935$ & 0,0132 & $-0,3210$ & $-0,1721$ & $-0,0231$ & $-0,1683$ \\
Tingkat Signifikan & 0,001 & 0,885 & $<0,001$ & 0,166 & 0,803 & 0,054 \\
Signifikan? (Ya/Tidak) & & Ya & Tidak & Ya & Tidak & Tidak & Tidak \\
\hline
\end{tabular}

Pada tabel 8 dibawah menunjukkan bahwa responden yang sering berjalan kaki (lebih dari sekali dalam seminggu) cenderung lebih rendah melakukan kesalahan error dan lebih sering menunjukkan perilaku positif dibandingkan dengan responden yang jarang berjalan kaki (kurang dari sekali dalam seminggu). Hasil frekuensi berjalan kaki tidak menunjukkan adanya pengaruh pada perilaku lapses, violations, perilaku agresif, dan pelanggaran lampu lalu lintas. Barangkali mereka yang sering berjalan kaki lebih mengetahui efek bahaya melanggar peraturan lalu lintas. Hasil ini dapat dilihat pada tingkat signifikan yang masing-masing bernilai 0,043 pada erors dan 0,021 pada perilaku positif.

Tabel 8. Uji selisih rataan berdasarkan frekuensi berjalan kaki

\begin{tabular}{|c|c|c|c|c|c|c|c|}
\hline \multirow{2}{*}{$\begin{array}{c}\text { Frekuensi Berjalan } \\
\text { Kaki }\end{array}$} & \multirow{2}{*}{$\mathrm{N}$} & \multicolumn{6}{|c|}{ Nilai Selisih Rataan } \\
\hline & & Lapse & Agresif & Violation & Error & Lampu LL & Positif \\
\hline $\begin{array}{l}\text { Kurang dari } \\
\text { dalam semali }\end{array}$ & 60 & 1,4542 & 1,3375 & 1,5867 & 2,3683 & 1,3167 & 1,1000 \\
\hline $\begin{array}{l}\text { Lebih dari sekali dalam } \\
\text { seminggu }\end{array}$ & 90 & 1,4139 & 1,2500 & 1,5433 & 2,1200 & 1,2722 & 1,2778 \\
\hline Selisih Rataan & & 0,0403 & 0,0875 & 0,0433 & 0,2483 & 0,0444 & $-0,1778$ \\
\hline Tingkat Signifikan & & 0,674 & 0,334 & 0,628 & 0,043 & 0,628 & 0,021 \\
\hline Signifikan? (Ya/Tidak) & & Tidak & Tidak & Tidak & Ya & Tidak & $\mathrm{Ya}$ \\
\hline
\end{tabular}

Pada tabel 9 dibawah menunjukkan bahwa tidak ada perbedaan secara signifikan antara responden yang mampu berjalan jarak jauh ( $\geq 500$ meter) dan jarak dekat ( $<500$ meter). Hal ini dapat dilihat dari nilai signifikansi yang lebih dari 0,05 . 
Tabel 9. Uji selisih rataan berdasarkan jarak kemampuan berjalan

\begin{tabular}{lccccccc}
\hline \multirow{2}{*}{$\begin{array}{c}\text { Jarak Kemampuan } \\
\text { Berjalan }\end{array}$} & \multirow{2}{*}{$\mathrm{N}$} & \multicolumn{5}{c}{ Nilai Selisih Rataan } \\
\cline { 3 - 7 } & & Lapse & Agresif & Violation & Error & Lampu LL & Positif \\
\hline < 500meter & 115 & 1,3891 & 1,2935 & 1,5617 & 2,2304 & 1,2783 & 1,2000 \\
< 500meter & 35 & 1,5643 & 1,2571 & 1,5571 & 2,1829 & 1,3286 & 1,2286 \\
Selisih Rataan & & $-0,1752$ & 0,0363 & 0,0046 & 0,0476 & $-0,0503$ & $-0,0286$ \\
Tingkat Signifikan & & 0,113 & 0,729 & 0,965 & 0,740 & 0,636 & 0,778 \\
Signifikan? (Ya/Tidak) & & Tidak & Tidak & Tidak & Tidak & Tidak & Tidak \\
\hline
\end{tabular}

Pada tabel 10 dibawah menunjukkan bahwa keterlibatan dalam kecelakaan memengaruhi kelompok variabel perilaku agresif dan violations. Hasil ini menyatakan bahwa kecelakaan pejalan kaki adalah akibat dari pelanggaran peraturan lalu lintas. Nilai signifikan pada perilaku agresif dan violations masing-masing memiliki nilai kurang dari persyaratan yaitu 0,05 .

Tabel 10. Uji selisih rataan berdasarkan keterlibatan dalam kecelakaan

\begin{tabular}{lccccccc}
\hline \multicolumn{1}{c}{ Keterlibatan dalam } & \multirow{2}{*}{ Kecelakaan } & $\mathrm{N}$ & \multicolumn{5}{c}{ Nilai Selisih Rataan } \\
\cline { 3 - 7 } & & Lapse & Agresif & Violation & Error & Lampu LL & Positif \\
\hline Ya, Pernah & 8,0938 & 1,6875 & 1,9250 & 2,3750 & 1,4375 & 1,1250 \\
Tidak Pernah & 142 & 1,3926 & 1,2623 & 1,5401 & 2,2106 & 1,2817 & 1,2113 \\
Selisih Rataan & & 0,7011 & 0,4252 & 0,3849 & 0,1644 & 0,1558 & $-0,0863$ \\
Tingkat Signifikan & & 0,091 & 0,030 & 0,047 & 0,542 & 0,611 & 0,651 \\
Signifikan? (Ya/Tidak) & & Tidak & Ya & Ya & Tidak & Tidak & Tidak \\
\hline
\end{tabular}

\section{KESIMPULAN DAN SARAN}

\section{Kesimpulan}

Berdasarkan penelitian yang telah dilakukan dapat disimpulkan bahwa perilaku pejalan kaki di Indonesia terutama wilayah Jabodetabek terbagi menjadi enam faktor: lapses, violations, errors, perilaku agresif, pelanggaran lampu lalu lintas, dan perilaku positif. Masing-masing dari enam faktor yang diuji terdapat dua faktor yang tidak reliabel yaitu errors dan perilaku positif. Sehingga perilaku positif dan kesalahan errors perlu di ekspansi lebih lanjut.

Kemudian secara signifikan jenis kelamin, tempat tinggal, tempat bekerja dan jarak kemampuan berjalan tidak memengaruhi keenam faktor perilaku pejalan kaki. Namun, kelompok usia, jenis pekerjaan, pengeluaran per bulan, frekuensi berjalan kaki, dan keterlibatan dalam kecelakaan memengaruhi perilaku pejalan kaki di Indonesia.

\section{Saran}

Diharapkan penelitian ini dapat membantu para pejalan kaki menyadari peraturan lalu lintas dan mengubah kecenderungan perilaku mereka yang membahayakan saat menyeberang maupun saat interaksi dengan pengguna jalan lainnya. Selain itu, diharapkan PBQ dapat berguna dalam penelitian keselamatan pejalan kaki dalam keadaan tertentu, misalnya perubahan perilaku pejalan kaki karena perubahan infrastruktur lalu lintas.

Selain itu, untuk penelitian selanjutnya diharapkan mengkaji lebih banyak referensi bila perlu melakukan observasi lapangan terkait dengan perilaku pejalan kaki di Indonesia agar hasil penelitiannya dapat lebih baik dan lebih lengkap lagi. Menambah jumlah responden untuk mendapatkan hasil yang lebih valid. Untuk membuat pejalan kaki lebih aman dalam lalu lintas direkomendasikan meningkatkan kuesioner dan menambah pertanyaan yang lebih jelas terkait keterlibatan pejalan kaki dengan teknologi sebagai faktor.

\section{DAFTAR PUSTAKA}

Antić, Boris, et al. (2016). Pedestrian Behaviours: Validation of the Serbian Version of the Pedestrian Behaviour Scale. Transportation Research Part F: Traffic Psychology and Behaviour. 170-78.

Deb, Shuchisnigdha, et al. (2017). Evaluating Pedestrian Behavior at Crosswalks: Validation of a Pedestrian Behavior Questionnaire for the U.S. Population. Accident Analysis and Prevention. 91-201.

Elliott, Mark A., and Christopher J. Baughan. (2004). Developing a Self-Report Method for Investigating Adolescent Road User Behaviour. Transportation Research Part F: Traffic Psychology and Behaviour. 373-393.

Granié, Marie Axelle, et al. (2013). Developing a Self-Reporting Method to Measure Pedestrian Behaviors at All Ages. Accident Analysis and Prevention. 830-839.

Junaedi, Tas'an. (2014). Analisis Keselamatan Pejalan Kaki Pada Simpang Bersinyal. Jurnal Rekayasa. 217-226. 
Papadimitriou, Eleonora, et al. (2016). Introducing Human Factors in Pedestrian Crossing Behaviour Models. Transportation Research Part F: Traffic Psychology and Behaviour. 69-82.

Putranto, Leksmono S., and Farah R. Ananda. (2021). The Development of Indonesian Pedestrian Behaviour Questionnaire. Tarumanagara International Conference on the Application of Technology and Engineering.

Tiwari, Geetam, et al. (2007). Survival Analysis: Pedestrian Risk Exposure at Signalized Intersections. Transportation Research Part F: Traffic Psychology and Behaviour. 77-89.

WHO. (2013). Keselamatan Pejalan Kaki Manual Keselamatan Jalan. WHO. 12-15.

Zhang, Guangnan, et al. (2014). Analyzing Fault and Severity in Pedestrian-Motor Vehicle Accidents in China. Accident Analysis and Prevention. 141-150. 
